\title{
New ostracod (Crustacea) species of the genus Robertsonites from the Upper Pliocene Kuwae and Sasaoka formations, central and northeast Japan
}

\author{
KATSURA YAMADA \\ Graduate School of Natural Science and Technology, Kanazawa University, Kakuma Kanazawa 920-1192, Japan \\ (e-mail: kyamada@kenroku.kanazawa-u.ac.jp)
}

\begin{abstract}
The ostracod genus Robertsonites is widely distributed in high-latitude seas of the Northern Hemisphere. It also occurs abundantly in Plio-Pleistocene strata along the coast of the Sea of Japan, which were deposited under the influence of the Japan Sea Proper Water mass, below $150 \mathrm{~m}$. The assemblages of the genus Robertsonites in the seas around Japan are quite different from those in the high-latitude seas of the Northern Hemisphere. A difference in the valve outlines of the genus in the two areas is also apparent. Nine species of the genus Robertsonites are restricted to strata and marine deposits around Japan, although only 12 species have been described world-wide, including the three new taxa described here. The Upper Pliocene Sasaoka and Kuwae formations in northeast and central Japan, contain seven species, including three new taxa, Robertsonites irizukii sp. nov., Robertsonites leptoreticulata sp. nov., and Robertsonites tabukii sp. nov., and one open-nomenclature taxon. J. Micropalaeontol. 22(2): 169-181, November 2003.
\end{abstract}

\section{INTRODUCTION}

Plio-Pleistocene strata, distributed along the coast of the Sea of Japan in central and northern Japan, contain many fossil ostracods. Many workers have studied these ostracods (Okada, 1979; Ishizaki \& Matoba, 1985; Tabuki, 1986; Cronin \& Ikeya, 1987; Irizuki, 1989, 1993, 1996; Irizuki \& Sasaki, 1993; Ishizaki et al., 1993; Cronin et al., 1994; Kamiya et al., 1996, 2001; Ozawa, 1996; Ozawa \& Kamiya, 2001; Yamada et al., 2002a). Plio-Pleistocene ostracods in Japan are characterized by highly diversified cool-water elements, comprising the Omma-Manganji-type fauna (Cronin \& Ikeya, 1987), some species of which are extinct. Indeed, circumpolar taxa living in the Arctic Ocean, North Atlantic Ocean and the Gulf of Alaska have been reported in abundance in the Plio-Pleistocene deposits of Japan. They are very important as a cold water and bathyal index for the reconstruction of Plio-Pleistocene palaeoceanography in the seas around Japan (e.g. Cronin \& Ikeya, 1987).

The Sea of Japan is a marginal sea that is almost enclosed by land. Oceanic structures and environments at the bottom of the Sea of Japan have changed dynamically since the Miocene (e.g. Tada, 1994). Since then, a succession of taxa have inhabited the area. In particular, Plio-Pleistocene climates were determined by glacial and inter-glacial conditions, resulting in distinct faunal changes.

The genus Robertsonites described by Swain (1963) is common in the fossil ostracod faunas of Plio-Pleistocene deposits in Japan, and also characterizes modern ostracod faunas of the Japan Sea Proper Water mass deeper than $150 \mathrm{~m}$ (e.g. Tsukawaki et al., 2000). Published studies show that, of the ten known species belonging to the genus Robertsonites in the world, six of them were present in Japan except for $R$. antarcticus Neale, R. logani (Brady \& Crosskey) and $R$. williamsi Cronin. Most species live in the high latitude seas of the Northern Hemisphere (e.g. Elofson, 1941) and, thus, they are treated as circumpolar and cryophilic species.

The Upper Pliocene strata of the Sasaoka and the Kuwae formations contain many fossil ostracods. Recently, cyclic changes of ostracod faunas caused by relative sea-level changes have been reported from the upper part of the Sasaoka Formation in the Gojome area, northeast Japan (Yamada et al., 2002a). The Kuwae Formation also records relative sea-level changes (Yamada et al., 2002b). Robertsonites species occur abundantly in these strata and show important vertical changes of relative abundance in both formations. In this paper, three new species are described.

\section{GEOLOGICAL SETTING}

Plio-Pleistocene strata were widely distributed in Niigata and Akita prefectures, in central and northeast Japan. Neogene strata are present in Akita Prefecture. The Sasaoka Formation is distributed in a general north-south direction from the Gojome area to the northern part of Akita City, northeast Japan, and is composed mainly of $560-700 \mathrm{~m}$ of thick grey muddy, fine-grained sandstones. Many well-preserved molluscs are enclosed in these muddy, fine-grained sandstones, some of which are preserved in life orientation. The Sasaoka Formation conformably and transitionally overlies the Tentokuji Formation, which consists of yellow-coloured weathered massive mudstone in the Gojome area (Yamada et al., 2002a). Few macrofossils have been found in the Tentokuji Formation.

The middle to upper part of the Sasaoka Formation is continuously exposed in a large outcrop about $200 \mathrm{~m}$ thick along the Babame River (Fig. 1). The deposits are divided into three parts based on lithology. The lower part consists of muddy, fine-grained sandstone with fossil molluscs, as noted above, and is characterized by many lenticular cross-beds. The middle portion is composed of muddy, fine-grained sandstone intercalated with parallel-laminated beds several centimetres thick. The upper part consists of alternating beds of muddy, fine-grained sandstone, fine-grained sandstone and mediumto coarse-grained sandstone. The Machimura section of the Sasaoka Formation has been investigated for fossil molluscs and foraminifers (Hase \& Hirayama, 1970), molluscs (Honda, 1978; Shimamoto, 1984; Matsui, 1985) and ostracods (Yamada et al., 2002a). Fossil ostracods suggest that one cycle of relative 
K. Yamada

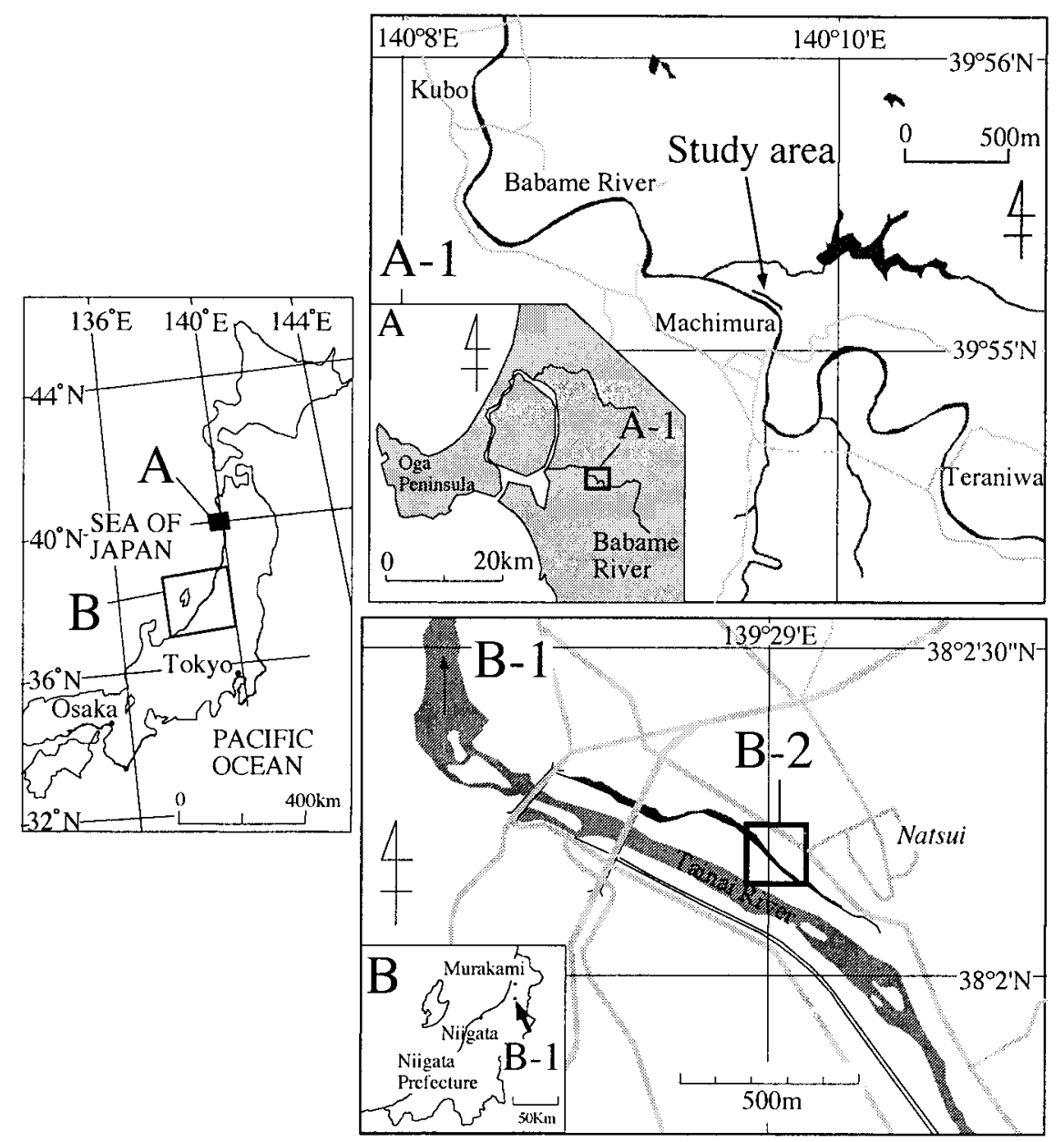

Fig. 1. Maps showing locations of the study areas: (A) Sasaoka Formation; (B) Kuwae Formation. Map B-2 tallies with that in Fig. 3.

sea-level change was recorded in each lithological unit of this section (Yamada et al., 2002a). Fossil molluscan assemblages suggest that the middle part of the Sasaoka Formation in the Machimura section was deposited in the lower neritic zone (Shimamoto, 1984) and the neritic zone (Honda, 1978).

The Kuwae Formation is located in the northern part of Shibata City and Kurokawa Village, Niigata Prefecture, central Japan. The upper Kuwae Formation, which crops out continuously in the Natsui section, Kurokawa Village, Niigata Prefecture, central Japan (Fig. 1), is composed of sandy siltstone. In this section the formation, which is about $200 \mathrm{~m}$ thick, unconformably overlies the Uchisugawa Formation of Miocene age which is composed of siliceous mudstone (Hiramatsu \& Miwa, 1998). Medium- to coarse-grained sandstone beds, several tens of centimetres thick, are intercalated in the sandy siltstone. The uppermost part of the Kuwae Formation here contains shell fragments and lenticular cross-beds. Diatoms, calcareous nannofossils and foraminifers (e.g. Kobayashi \& Watanabe, 1985; Hiramatsu \& Miwa, 1998), and ostracods (Shoji et al., 2002; Yamada et al., 2002b) have been studied. Benthic foraminiferal assemblages in this section show that the upper part of the Kuwae Formation was deposited in the upper bathyal zone and the lower neritic zone (Takano et al., 2001).
The genus Robertsonites occurs with abundant Krithe spp. in this section (Yamada et al., 2002b).

The study interval of the Sasaoka Formation has been dated at about 2.20-2.05 $\mathrm{Ma}$ on the basis of calcareous nannofossil data and magnetostratigraphy (Hoshi et al., 2001; Yamada et al., 2002a). The Kuwae Formation has been dated at about 2.80-2.55 Ma on the basis of calcareous nannofossils and diatoms (Yamada et al., 2002b).

\section{MATERIALS AND METHODS}

Eighty-three samples were collected from the upper part of the Sasaoka Formation in the Machimura section (Fig. 2); the samples being the same as those studied by Yamada et al. (2002a). One hundred and three samples from the upper Kuwae Formation in the Natsui section were also used in this study (Fig. 3). Fossil ostracods are well preserved and abundant in both sections. Eighty-gram dried sediment samples were disaggregated by the sodium sulphate and naphtha methods of Maiya \& Inoue (1973), washed through a $75 \mu \mathrm{m}$ sieve, and then dried at $50{ }^{\circ} \mathrm{C}$. The resultant residues were divided into aliquots containing 100-200 specimens. The fossil ostracods were picked from the fraction coarser than $125 \mu \mathrm{m}$. 


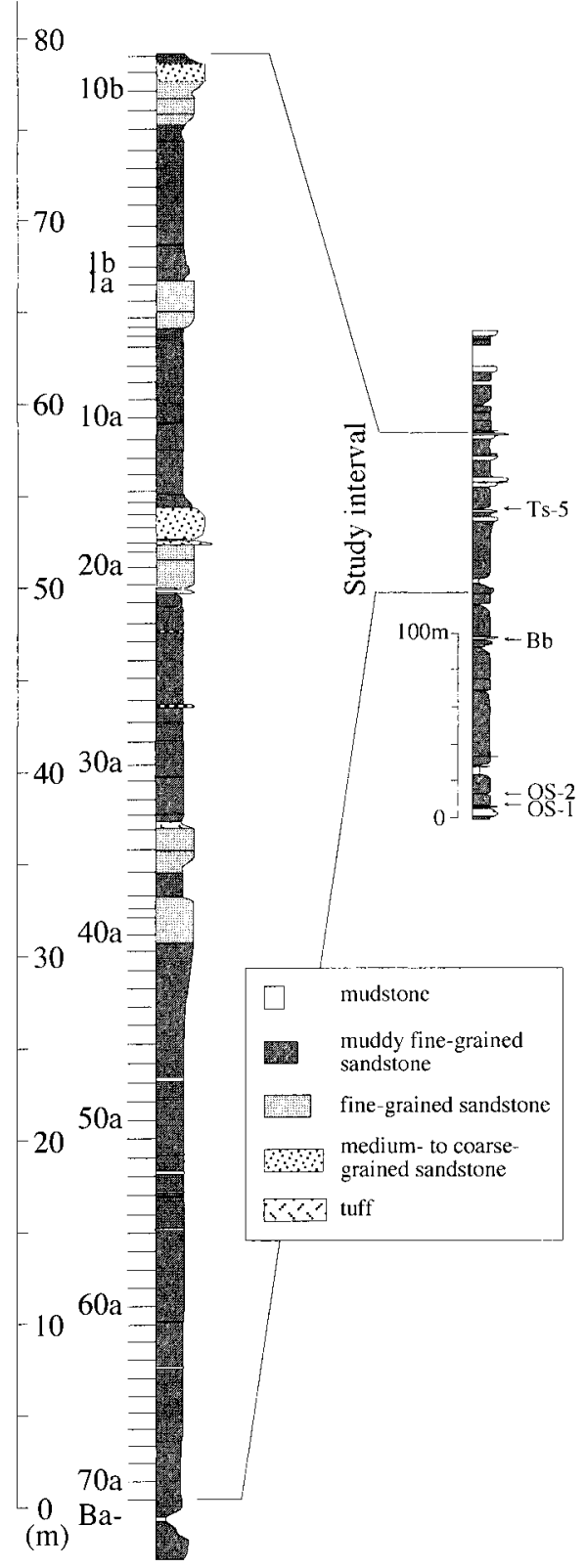

Fig. 2. Columnar section from the Babame River outcrop and the study interval, the upper part of the Sasaoka Formation. OS-1, OS-2, Bb and Ts-5 indicate key tuff layers. The numbers on the left side of the columnar section (e.g. Ba-1a) show sample numbers. For location of this outcrop, see Fig. 1.

\section{SYSTEMATIC DESCRIPTIONS}

All specimens used in this study are deposited in the collections of the Institute of Geoscience, University of Tsukuba with IGUT catalogue numbers. The size convention described by Whatley \& Boomer (2000) is used for the adult ostracod valves documented below.

Order Podocopida Sars, 1866

Superfamily Cytheroidea Baird, 1850

Family Trachyleberididae Sylvester-Bradley, 1948
Subfamily Buntoniinae Apostolescu, 1961

Genus Robertsonites Swain, 1963

Robertsonites hanaii Tabuki, 1986

(Pl. 1, figs 1-2)

1982 Robertsonites ? reticuliforma (Ishizaki, 1966); Yajima: 205, pl. 12, fig 13 .

1987 Robertsonites hanaii Tabuki; Cronin \& Ikeya: 81, pl. 2, fig 11.

1992 Robertsonites hanaii Tabuki; Ikeya \& Suzuki: 135, pl. 8, fig 5.

1994 Robertsonites hanaii Tabuki; Irizuki: 11, pl. 2, fig 7.

Occurrence. Found in the Miocene to Recent sediments in Japan and in the seas around Japan. It was found in 19 samples from the Kuwae Formation (Kwe101, 107, 117, 119, 160, 162, 165, 29 u, 28.5u, 28.3u, 26.5u, 23u, 21u, 16u, 15u, 10u, 08u, 06u, 02u) and 14 samples from the Sasaoka Formation $(\mathrm{Ba}-4 \mathrm{a}, 5 \mathrm{a}, 19 \mathrm{a}$, 22a, 31a, 32a, 33a, 34a, 35a, 39a, 40a, 50a, 54a, 58a).

Remarks. This species was first described from the PlioPleistocene Daishaka Formation by Tabuki (1986), and is also found in the Miocene to Recent sediments in Japan and the seas around the Japanese Islands. Specimens recovered from the Sasaoka and the Kuwae formations, which were mainly juveniles, have slightly tapered posterior margins.

\section{Robertsonites irizukii sp. nov.}

(Fig. 4a, Pl. 1, figs 3-7)

Derivation of name. In honour of $\mathrm{Dr} T$. Irizuki (Shimane University, Japan), who is a specialist of Cenozoic fossil ostracods of Japan.

Diagnosis. Carapace very large-sized, elongate, subquadrate and heavily calcified. The lateral outline is similar to that of $R$. tuberculatus, but quite differ from those of other Robertsonites species described from Japanese Island and its adjacent seas. Fine reticulation and weak ridges are found on valve surface.

Holotype. Male, left valve, IGUT no. 50300 (Pl. 1, figs 3, 5, 7).

Paratypes. Male, right valve, IGUT no. 50301 (Pl. 1, figs 4, 6). Female, right valve, IGUT no. 50302 (Fig. 4a).

Material. 38 valves. 8 adults and 30 juveniles.

Type locality and horizon. Natsui section, the Upper Pliocene Kuwae Formation, Kurokawa Village, Niigata Prefecture, central Japan. Loc. Kwe051. (Lat. 38 2 2'10" N, Long. 139 29' 1" E).

Description. Valves very large-sized, elongate, subquadrate in lateral view, and heavily calcified. Maximum height at anterior cardinal angle. Anterior margin broadly rounded. Dorsal margin straight. Ventral margin nearly straight, but ventral contact margin slightly concave in the middle of valve length. Posterior margin rounded and tapered at middle of valve height.

Surface ornamented with fine reticulation and feeble ribs, eye tubercle and subcentral tubercle. Fossae distinct, small but 


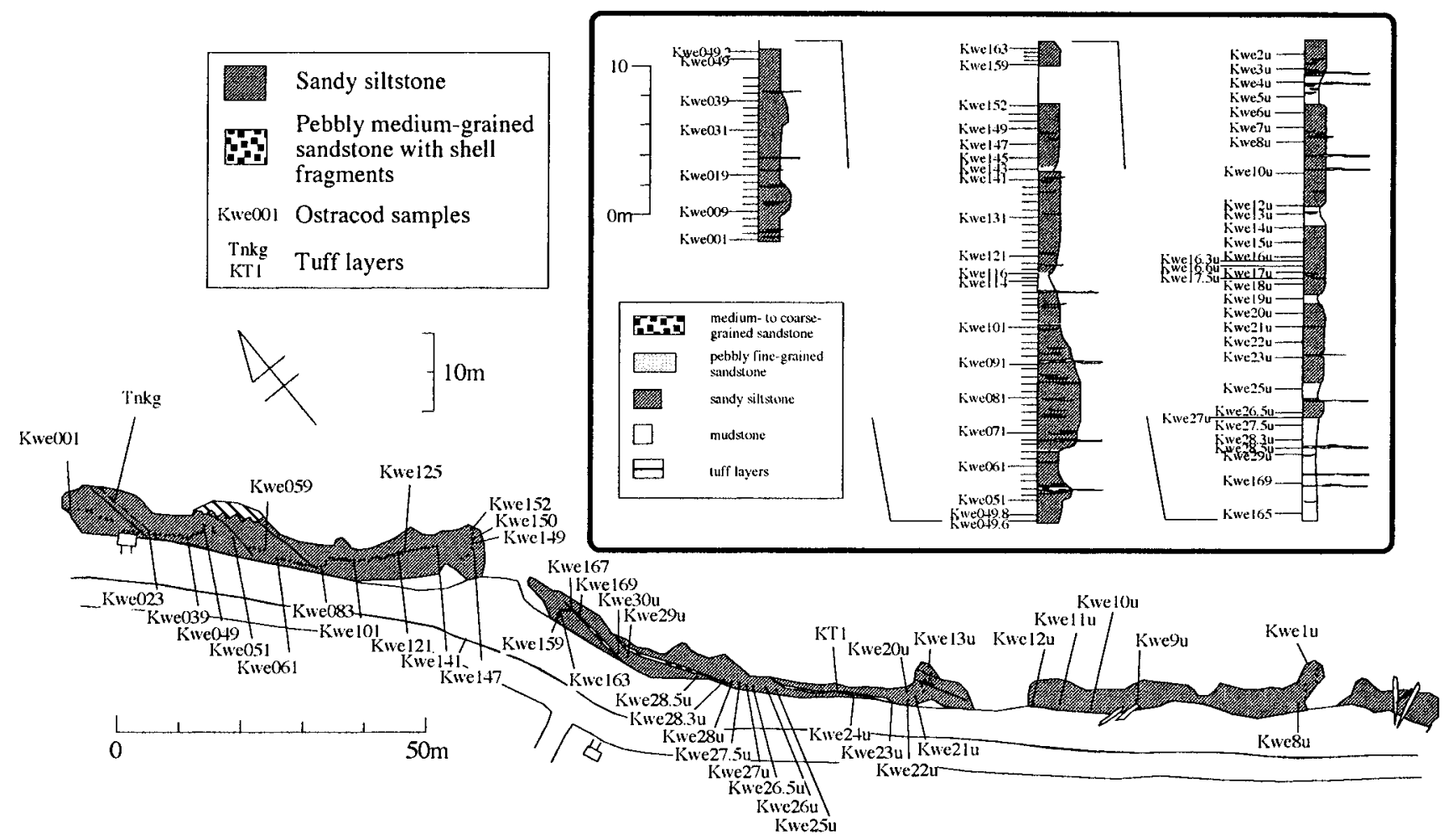

Fig. 3. Map and columnar section of the upper part of the Kuwae Formation in the Natsui section, Niigata Prefecture, central Japan.

becoming slightly larger in anterior and posterior areas. Distinct rib starting at anteroventral area, running parallel with the ventral margin, and terminating at posterior one-third of valve length. Weak ridge running along anterior and ventral margins. Ventral submarginal surface bears two or three longitudinal narrow ridges. Eye tubercle prominent in the anterodorsal area. Subcentral tubercle developed.

Calcified inner lamella moderately broad along anterior and posterior margin, and narrow along ventral margin. Marginal pore canals straight, number 69. Hingement holamphidont: in left valve, anterior element is a large elongate socket with pit; anteromedian element is a tongue like tooth; posteromedian element is a bar; posterior element is an elongate socket. Muscle scars inside the subcentral tubercle consist of a vertical row of four adductor scars and V-shaped frontal scar. Normal pores scattered. Vestibule developed in anteroventral and posterior areas.

Sexual dimorphism prominent. Males more slender than females.

Dimensions. Holotype, left valve, male (Pl. 1, figs 3, 5, 7) $1.08 \mathrm{~mm}$ long and $0.60 \mathrm{~mm}$ high; Paratype, right valve, male (Pl. 1, figs 4, 6) $1.08 \mathrm{~mm}$ long and $0.58 \mathrm{~mm}$ high, right valve, female (Fig. 4a) $1.10 \mathrm{~mm}$ long and $0.63 \mathrm{~mm}$ high.

Occurrence. The Kuwae Formation of Late Pliocene age in the Natsui section, Kurokawa Village, central Japan. This species was recorded in 16 samples (Kwe001, 011, 021, 029, 051, 059, $061,069,079,085,087,093,095,097,101,109)$ from the Natsui section of the Kuwae Formation.
Remarks. This species is related to Robertsonites tuberculatus (Sars, 1866), in the outline of the valves, but is different from the latter in the nature of the valve surface and ribs. The valve surface of the present species is covered by fine pits. The posterodorsal margin is slightly protruded in this species. The other species of genus Robertsonites reported from Japan, $R$. hanaii Tabuki, $R$. japonicus (Ishizaki), $R$. leptoreticulata sp. nov., $R$. reticuliforma (Ishizaki), $R$. tsugaruana Tabuki, $R$. tabukii sp. nov., and $R$. yatsukanus Tanaka, are quite different to this species in lateral outline.

\section{Robertsonites leptoreticulata $\mathrm{sp}$. nov.}

(Fig. 4b, Pl. 1, figs 8-16)

2002a Robertsonites sp. 3 Yamada et al.: 8, pl. 1, figs 9, 10.

Derivation of name. After the feeble reticulation of the valve surface.

Diagnosis. Carapace large-sized, sub-elliptical, tapering posteriorly and heavily calcified. Valve surface is ornamentated by faint reticulation and weak ridges. Degree of development of this ornamentation varies widely. This specimen differs from genus Robertsonites in lack of small pit in the anterior element of hingement in right valve.

Holotype. Female, left valve, IGUT no. 50303 (Pl. 1, figs 8, 12, 16).

Paratypes. Female, right valve, IGUT no. 50304 (P1. 1, figs 9, 13). Male, left valve, IGUT no. 50305 (Pl. 1, figs 10, 14). Male, 


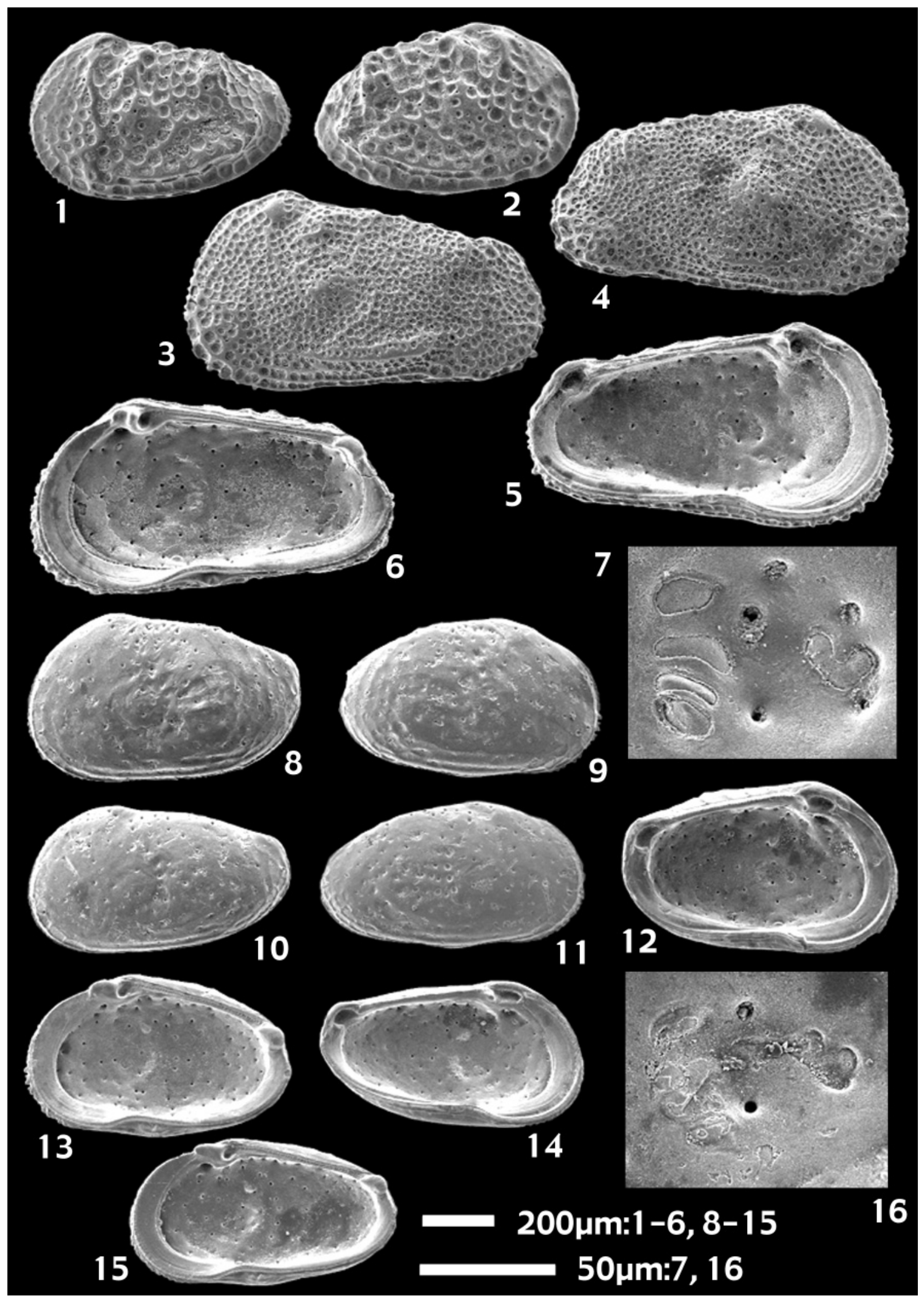

Explanation of Plate 1.

figs 1-2. Robertsonites hanaii Tabuki, 1986: 1, juvenile, left valve, loc. Kwe162; 2, juvenile, right valve, loc. Kwe117. figs 3-7. Robertsonites irizukii Yamada sp. nov.: 3, 5, 7, male, left valve (holotype), loc. Kwe051, IGUT no. 50300; 4, 6, male, right valve (paratype), loc. Kwe051, IGUT no. 50301. figs 8-16. Robertsonites leptoreticulata Yamada sp. nov.: 8, 12, 16, female, left valve (holotype), loc. Ba-21a, IGUT no. 50303; 9, 13, female, right valve (paratype), loc. Ba-21a, IGUT no. 50304; 10, 14, male, right valve (paratype), loc. Ba-52a, IGUT no. 50305; 11, 15, male, left valve (paratype), loc. Ba-23a, IGUT no. 50306. 
a

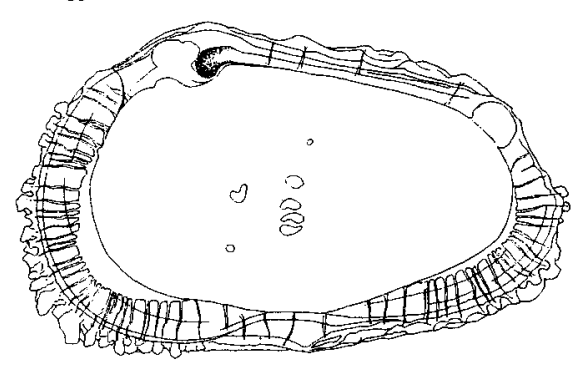

b

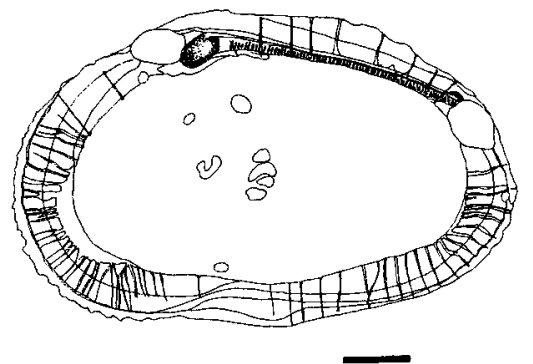

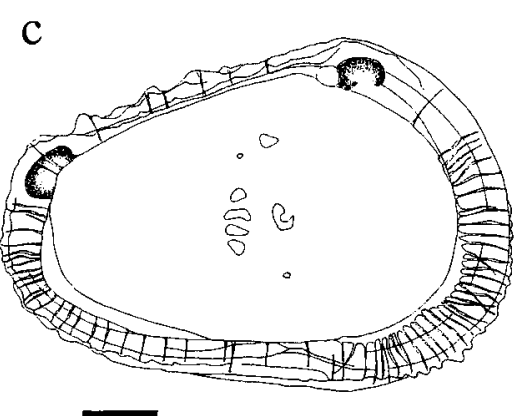

Fig. 4. Internal views of each species. (a) Robertsonites irizukii Yamada sp. nov., female, light valve, paratype, loc. Kwe 095, IGUT no. 50302; (b) Robertsonites leptoreticulata Yamada sp. nov., female, right valve, paratype, loc. Ba-23a, IGUT no. 50307; (c) Robertsonites tabukii Yamada sp. nov., female, left valve, paratype, loc. Kwe057, IGUT no. 50316. Scale bar $100 \mu \mathrm{m}$.

right valve, IGUT no. 50306 (Pl. 1, figs 11, 15), Female, right valve, IGCT no. 50307 (Fig. 4b).

Material. 5 carapaces and 451 valves. 86 adults and 370 juveniles.

Type locality and horizon. The Upper Pliocene Sasaoka Formation of the Machimura section of the Gojome area, Akita

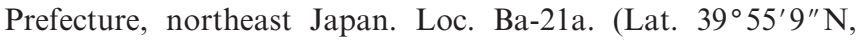
Long. $140^{\circ} 9^{\prime} 37^{\prime \prime} \mathrm{E}$ ).

Description. Valves large-sized, sub-elliptical, tapering posteriorly in lateral view, and heavily calcified. Maximum height at anterior cardinal angle. Anterior margin broadly rounded. Dorsal margin nearly straight in left valve. Ventral margin nearly straight, but ventral contact margin slightly concave in the middle of valve length. Posterior margin rounded in right valve, and obliquely rounded in left valve, merging imperceptibly into ventral margin. Lower half of anterior margin denticulate.

Surface ornamented with feeble reticulation, ridges, scattered pits and subcentral tubercle. Reticulation obscure in anterior part in female and most part in male. Distinct ridge extends from the anteroventral area along ventral margin, before curving toward the dorsal area at posterior one-fifth of valve length; projected in posteroventral area. Weak ridge extends along lower two-thirds of anterior margin to posteroventral area. Subcentral tubercle weakly developed.

Calcified inner lamella moderately broad along anterior and posterior margin, and narrow along ventral margin. Marginal pore canals straight, 61 in number. Hingement amphidont: in right valve, anterior element is a large elongate tooth; anteromedian element is a tongue-like socket; posteromedian element is finely crenulate groove; posterior element is an elongate tooth. Muscle scars inside the subcentral tubercle comprise a vertical row of four adductor scars and V-shaped frontal scar. Normal pores scattered. Vestibule developed in anteroventral and posterior areas.

Sexual dimorphism prominent. Males more slender than females.

Dimensions. Holotype, left valve, female (Pl. 1, figs 8, 12, 16) $0.80 \mathrm{~mm}$ long and $0.50 \mathrm{~mm}$ high; Paratype, right valve, female
(Pl. 1, figs 9, 13) $0.78 \mathrm{~mm}$ long and $0.48 \mathrm{~mm}$ high, left valve, male (Pl. 1, figs 10,14$) 0.77 \mathrm{~mm}$ long and $0.42 \mathrm{~mm}$ high, right valve, male (Pl. 1, figs 11,15$) 0.77 \mathrm{~mm}$ long and $0.45 \mathrm{~mm}$ high, right valve, female (Fig. 4b) $0.78 \mathrm{~mm}$ long and $0.47 \mathrm{~mm}$ high.

Occurrence. Late Pliocene (2.20-2.05 Ma) Sasaoka Formation in the Gojome area, northeast Japan. This species occurs in 32 samples (Ba-4a, 5a, 10a, 11a, 14a, 18a-30a, 32a, 33a, 38a, 41a, $42 \mathrm{a}, 44 \mathrm{a}-48 \mathrm{a}, 50 \mathrm{a}-52 \mathrm{a}, 63 \mathrm{a}, 65 \mathrm{a})$ in the study section of the Sasaoka Formation of Late Pliocene age (2.20-2.05 Ma), Gojome area, northeast Japan.

Remarks. This species is related to Robertsonites tsugaruana Tabuki (1986) in overall outline, but is different from the latter in surface reticulation and ridges, the posterior margin of the males, and in the hingement. The reticulation of this species is weaker than that of $R$. tsugaruana. The anterior element of hingement in right valve consists of elongate teeth in this species. The posterior margin of males is rounded in this species. The degree of development of the posterior ridge and reticulation on the lateral surface in the posterocentral area is variable from specimen to specimen.

\section{Robertsonites sp. \\ (Pl. 2, figs 1, 2)}

Diagnosis. Carapace very large-sized, sub-ellipsoidal and tapering posteriorly. Surface with fine reticulation and distinct marginal ridge in posteroventral area. Eye tubercle and oblique ridge extending anteriorly from below the eye tubercle to one-third of the valve length are distinct.

Occurrence. Recorded in 11 samples from Sasaoka Formation (Upper Pliocene) in the Gojome area, northeast Japan from 11 samples (Ba-20a, 1b, 3b-11b).

Remarks. This species resembles $R$. japonicus (Ishizaki) in the general lateral outline of the valves and in the fine reticulation on the valve surface. However, it differs from the latter in its obscured marginal ridges. This species is also close to $R$. reticuliforma (Ishizaki) in the general lateral outline of valve, but differs from the latter in having fine reticulation and oblique ridge in anteromedian area. 


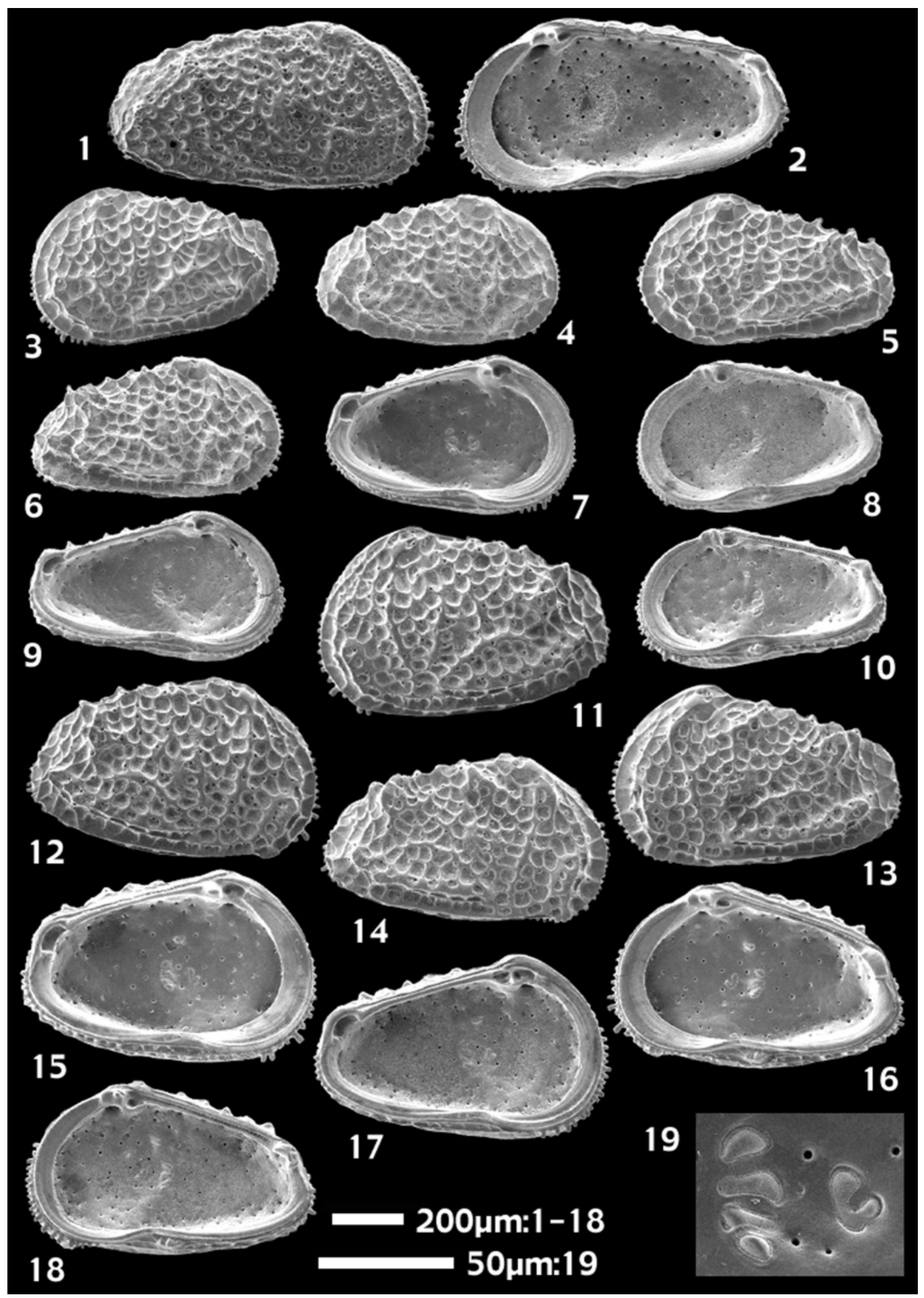

Explanation of Plate 2.

figs 1-2. Robertsonites sp., male, right valve, loc. Ba-11b. figs 3-19. Robertsonites tabukii Yamada sp. nov.: 3, 7, 19, female, left valve (holotype), loc. Kwe097, IGUT no. 50308; 4, 8, female, right valve (paratype), loc. Kwe057, IGUT no. 50309; 5, 9, male, left valve (paratype), loc. Kwe003, IGUT no. 50310; 6, 10, male, right valve (paratype), loc. Kwe003, IGUT no. 50311; 11, 15, female, left valve (paratype), loc. Kwe013, IGUT no. 50312; 12, 16, female, right valve (paratype), loc. Kwe013, IGUT no. 50313; 13, 17, male, left valve (paratype), loc. Kwe021, IGUT no. 50314; 14, 18, male, right valve (paratype), loc. Kwe021, IGUT no. 50315. 
Robertsonites tabukii sp. nov.

(Fig. 4c, Pl. 2, figs 3-19)

1985 Buntonia ? sp. Ishizaki \& Matoba: 17, pl. 2, fig 6. 1986 Robertsonites reticuliforma (Ishizaki, 1966); Tabuki: 148, pl. 14, figs $1-12$.

1987 Robertsonites reticuliforma Tabuki; Cronin \& Ikeya: 81, pl. 2, fig 15 .

1994 Robertsonites reticuliforma (Ishizaki, 1966); Irizuki: 11, pl. 2, figs 4-6.

1996 Robertsonites reticuliforma (Ishizaki, 1966); Irizuki: 29, figs $7-3,4$.

Derivation of name. After Dr R. Tabuki (Ryukyu University), who has investigated the Plio-Pleistocene Daishaka Formation, Aomori Prefecture, northeast Japan.

Diagnosis. Carapace large-sized, sub-elliptical, tapering posteriorly and heavily calcified. Distinct reticulation and the obliquely disposed ridges of anterior and ventral areas are on the lateral surface. Valve size varies widely between $0.70 \mathrm{~mm}$ and $0.88 \mathrm{~mm}$ in length and $0.45 \mathrm{~mm}$ and $0.63 \mathrm{~mm}$ in height.

Holotype. Female, left valve, IGUT no. 50308 (Pl. 2, figs 3, 7, 19).

Paratypes. Female, right valve, IGUT no. 50309 (Pl. 2, figs 4, 8). Male, left valve, IGUT no. 50310 (Pl. 2, figs 5, 9). Male, right valve, IGUT no. 50311 (P1. 2, figs 6, 10), Female, left valve, IGUT no. 50312 (Pl. 2, figs 11, 15), Female, right valve, IGUT no. 50313 (Pl. 2, figs 12, 16). Male, left valve, IGUT no. 50314 (Pl. 2, figs 13, 17). Male, right valve, IGUT no. 50315 (Pl. 2, figs 14, 18), Female, left valve, IGUT no. 50316 (Fig. 4c).

Material. 1 carapace and 1084 valves; 77 adults and 1008 juveniles.

Type locality and horizon. Loc. Kwe097. (Lat. 38 2' 9" N, Long. $139^{\circ} 29^{\prime} 2^{\prime \prime} \mathrm{E}$ ) of the Natsui section, Kuwae Formation (Upper Pliocene), Kurokawa Village, Niigata Prefecture, central Japan.

Description. Valve large-sized, sub-elliptical, tapering posteriorly in lateral view, and heavily calcified. Maximum height at anterior cardinal angle. Anterior margin broadly rounded with several spines. Dorsal margin nearly straight. Ventral margin nearly straight, but ventral contact margin slightly concave in the middle of valve length. Posterior margin broadly rounded and well formed cardinal angle in the left valve.

Surface ornamented with coarse reticulation, ridges and faint subcentral tubercle. Anterior ridge runs along anterior margin in the lower two-thirds of valve height. Anteroventral elongate swelling developed. Ventral ridge prominent, starting at termination of anterior ridge, runs parallel to ventral margin, and extends into a projection at ventrally one-third of valve height. Posterior ridge truncated at mid-height. Distinct ridge extends from below eye tubercle, runs obliquely to the ventral ridge at anterior quarter of valve length. Strong posteroventral ridge runs laterally to just in front of mid-length. Several short denticles occur on the lower half of anterior and posterior margin. Subcentral tubercle and eye tubercle are feeble.
Calcified inner lamella moderately broad along anterior margin, and narrow along posterior and ventral margins. Most marginal pore canals straight, number 67. Hingement holamphidont: in left valve, anterior element is a socket with small pit; anteromedian element is a tooth; posteromedian element is finely crenulate median groove; posterior element is a large socket. Muscle scar at subcentral area comprises a vertical row of four adductor scars and J-shaped frontal scar. Normal pores scattered. Vestibule developed in anterior and posterior areas.

Sexual dimorphism prominent. Males more slender than females.

Dimensions. Holotype, left valve, female (Pl. 2, figs 3, 7, 19) $0.73 \mathrm{~mm}$ long and $0.47 \mathrm{~mm}$ high; Paratype, right valve, female (Pl. 2, figs 4, 8) $0.72 \mathrm{~mm}$ long and $0.45 \mathrm{~mm}$ high, left valve, male (Pl. 2, figs 5, 9) $0.77 \mathrm{~mm}$ long and $0.45 \mathrm{~mm}$ high, right valve, male (Pl. 2, figs 6,10$) 0.75 \mathrm{~mm}$ long and $0.42 \mathrm{~mm}$ high, left valve, female (Pl. 2, figs 11,15$) 0.88 \mathrm{~mm}$ long and $0.58 \mathrm{~mm}$ high, right valve, female (Pl. 2, figs 12, 16) $0.87 \mathrm{~mm}$ long and $0.55 \mathrm{~mm}$ high, left valve, male (Pl. 2, figs 13, 17) $0.87 \mathrm{~mm}$ long and $0.55 \mathrm{~mm}$ high, right valve, male (Pl. 2, figs 14,18$) 0.87 \mathrm{~mm}$ long and $0.55 \mathrm{~mm}$ high, left valve, female (Fig. 4c) $0.75 \mathrm{~mm}$ long and $0.48 \mathrm{~mm}$ high.

Occurrence. Plio-Pleistocene strata from Japan, and recent bottom sediments in the Sea of Japan. This species occurs in the Sasaoka Formation (9 samples; Ba-14a, 15a, 26a, 31a, 51a, 54a, 58a, 61a, 70a) and the Kuwae Formation (73 samples; Kwe001, 003, 005, 007, 009, 011, 013, 015, 017, 019, 021, 023, 029, 031, 037, 039, 041, 051, 057, 059, 061, 063, 067, 069, 071, 079, 083, 085, 087, 089, 091, 093, 095, 097, 099, 101, 103, 105, 107, 109, $111,114,115,116,117,129,131,133,135,137,141,143,147$, $159,160,161,165,29 u, 28.5$ u, 28.3u, 27.5u, 27u, 26.5u, 25u, 21u, $17 \mathrm{u}, 16.3 \mathrm{u}, 16 \mathrm{u}, 15 \mathrm{u}, 12 \mathrm{u}, 10 \mathrm{u}, 08 \mathrm{u}, 02 \mathrm{u})$ in the study section.

Remarks. This species is very similar to $R$. hanaii Tabuki in lateral valve outline and surface ornamentation. However, it differs from $R$. hanaii Tabuki by its smaller valve size, slightly elongate valve outline in both male and female, well-developed anteroventral elongate swelling, inflated carapace and strong posterior cardinal angle which gives the species an angular posterodorsal margin. The dimensions of this species vary widely (Fig. 5). Valve size of adults ranges from 0.70 to $0.88 \mathrm{~mm}$ in length and 0.45 to $0.63 \mathrm{~mm}$ in height.

\section{Robertsonites tsugaruana Tabuki, 1986}

(P1. 3, figs 1-5)

1986 Robertsonites tsugaruana Tabuki; 150, pl. 15, figs 1-12. 1996 Robertsonites tsugaruana Tabuki; Ozawa: 114, pl. 8, fig 7. 1996 Robertsonites tsugaruana Tabuki; Kamiya et al.: 163, pl. 3, fig 7.

2001 Robertsonites tsugaruana Tabuki; Kamiya et al.: 99, fig. 16.16 .

Diagnosis. Carapace large-sized, sub-elliptical and slightly angular posterodorsal margin in left valve. Fine reticulation, concentrical ridges and eye tubercle on valve surface. Hingement holamphidont. 
New ostracod (Crustacea) species of the genus Robertsonites

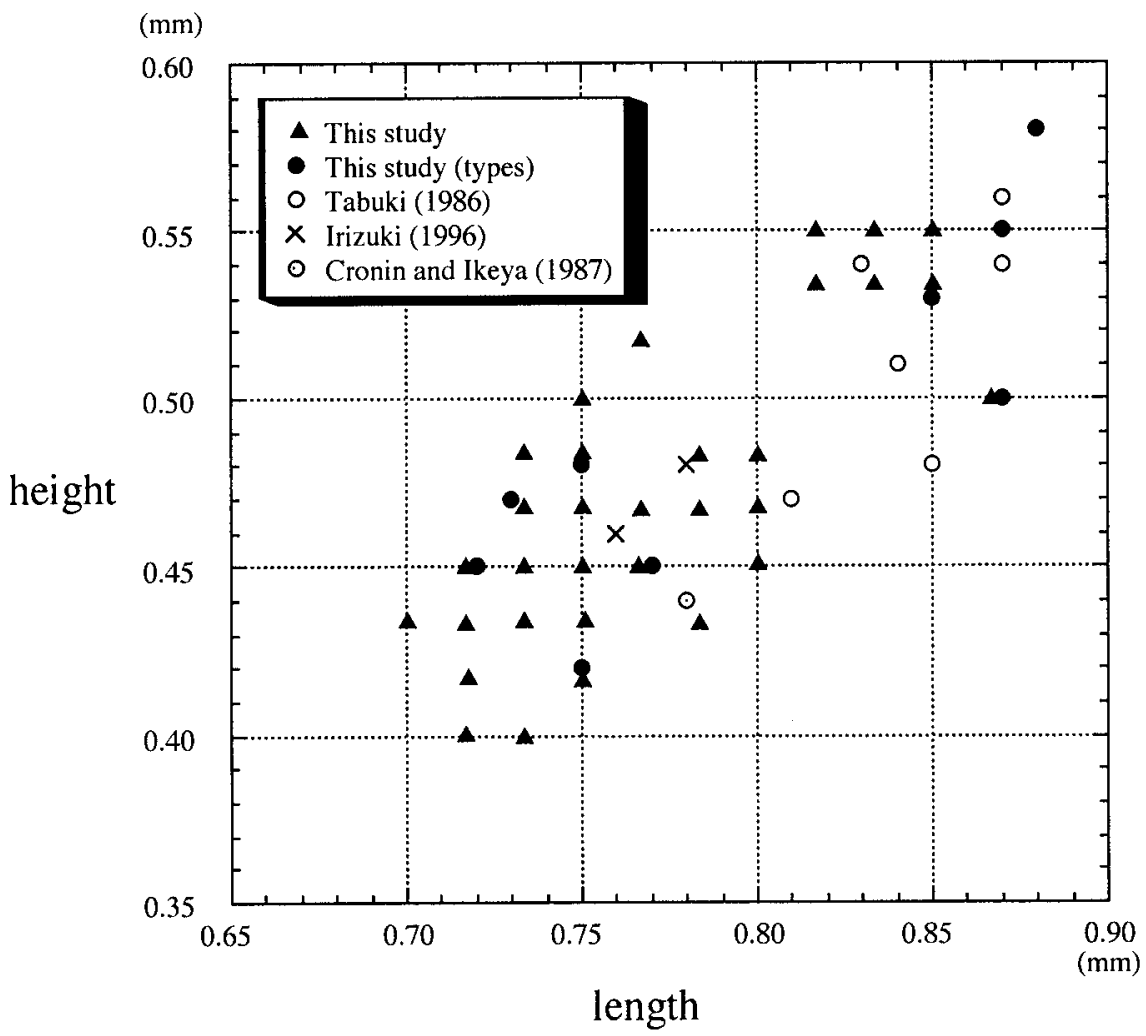

Fig. 5. Size variations (length:height ratio) of adult valves of Robertsonites tabukii Yamada sp. nov. Data from Tabuki (1986), Cronin \& Ikeya (1987), Irizuki (1996) and this study.

Occurrence. Upper Pliocene Sasaoka and Kuwae formations and Pleistocene Daishaka and Omma formations. This species is also reported from the bottom sediments in the Sea of Japan. It was recovered from one sample from the Sasaoka Formation (Ba-9b), and 12 samples from the Kuwae Formation (samples Kwe093, 165, 111, 116, 129, 131, 141, 160, 161, 16.3u, 12u, 08u).

Remarks. This species was first described from the Pleistocene Daishaka Formation in northeast Japan by Tabuki (1986), and occurs in the Pliocene Kuwae and Sasaoka formations and Pleistocene Omma Formation, central and northeast Japan.

\section{Robertsonites cf. yatsukanus Tanaka, 2002}

(P1. 3, figs 6-10)

2002 Robertsonites yatsukanus Tanaka; Tanaka et al.: 14, fig. 8.9-12.

Diagnosis. Carapace large-sized, sub-elliptical and heavily calcified. Coarse reticulation, ridges along anterior and ventral margins, S-shaped ridge in posterior area and eye tubercle are found on valve surface. Hingement holamphidont.

Occurrence. This species occurs in the Miocene Fujina Formation, southwest Japan, and the Upper Pliocene Sasaoka Formation, northeast Japan. It was recovered from 20 samples of the Sasaoka Formation (samples Ba-12a, 14a, 26a, 31a, 32a, 33a, 34a, 35a, 51a, 53a, 58a, 59a, 61a, 62a, 64a, 66a, 67a, 68a, 69a, 70a).
Remarks. This species was first described by Tanaka et al. (2002) from the Miocene Fujina Formation in southwest Japan. Specimens from the Sasaoka Formation differ from type specimens in having more heavily calcified carapace, well-developed ridges of the valve surface, and S-shaped posterior ridge.

\section{DISCUSSION}

As noted previously, the genus Robertsonites is mainly distributed in high-latitude seas and is a circumpolar and cryophilic taxon. The seas around the Japanese Islands constitute the southern limits of the habitat of the genus in the northwestern Pacific Ocean. The distribution of fossil and modern species of Robertsonites in Japan is known from published records and data (Ishizaki, 1966; Yajima, 1982; Ishizaki \& Matoba, 1985; Tabuki, 1986; Cronin \& Ikeya, 1987; Huh \& Paik, 1992; Ikeya \& Suzuki, 1992; Ishizaki et al., 1993; Cronin et al., 1994; Irizuki, 1994, 1996; Irizuki \& Matsubara, 1994, 1995; Kamiya et al., 1996; Ozawa, 1996; Tsukawaki et al., 1997, 1998, 1999, 2000, 2001; Ozawa et al., 1999; Yamada et al., 2001, 2002a, 2002b; Tanaka et al., 2002). Twelve taxa, including three new species and three open-nomenclature species, are reported here.

The data concerning this genus suggest that the associations of the genus Robertsonites in the seas around the Japanese Islands are quite different from those observed in other highlatitude seas of the Northern Hemisphere. Living $R$. tuberculatus (Sars) is widely distributed in the high latitudes of the Northern Hemisphere (the Arctic Sea, North Atlantic Ocean, and the Gulf of Alaska). However, it has never been reported from Recent 


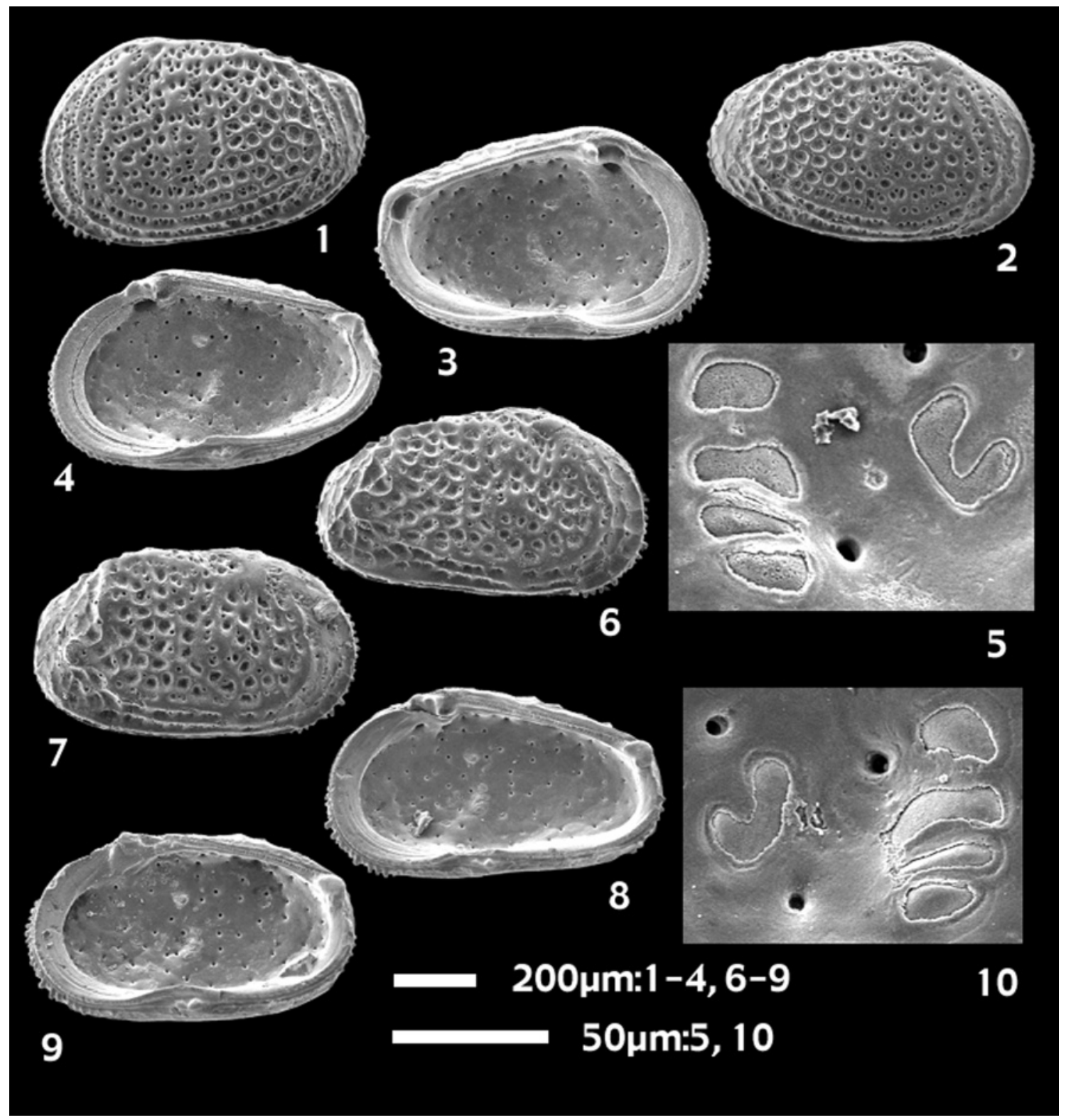

Explanation of Plate 3.

figs 1-5. Robertsonites tsugaruana Tabuki, 1986: 1, 3, 5, female, left valve, loc. Ba-9b; 2, 4, female, right valve, loc. Ba-9b. figs 6-10. Robertsonites cf. yatsukanus Tanaka, 2002: 6, 8, 10, male, right valve, loc. Ba-59a; 7, 9, female, right valve, loc. Ba-61a.

deposits in the seas around Japan. Robertsonites hanaii, $R$. reticuliforma, $R$. tabukii, and $R$. tsugaruana, which live in the seas around the Japanese Islands (Fig. 6), have not been reported from the northern oceans. In the northern seas one species, $R$. tuberculatus, is the most abundant of the genus, whereas another two species, $R$. logani and $R$. williamsi, have been reported from only a few samples. On the other hand four species, $R$. hanaii, $R$. reticuliforma, $R$. tabukii, and $R$. tsugaruana, occur at similar frequencies in the seas around the Japanese Islands, which is a relatively narrow area. Highly diversified associations of the genus Robertsonites are found in the Sea of Japan.

Evidence for the different associations of Robertsonites in the two areas is also provided by their valve shapes. The valve outlines of the four species from the Sea of Japan are quite different from that of $R$. tuberculatus. These observations have been described by Tabuki (1986) and Brouwers (1993).

Robertsonites tuberculatus lives in the sublittoral zone in the high-latitude seas of the Northern Hemisphere (e.g. Hazel, 1967; Neale \& Howe, 1975) and in the sublittoral and bathyal zones in the Gulf of Alaska (Brouwers, 1993) and its habitat depends on water temperature, as is also true of Acanthocythereis dunelmensis (e.g. Cronin \& Ikeya, 1987). However, in the present Sea of Japan, this taxon shows a more restricted bathymetric distribution. Ostracod associations in the present Sea of Japan are usually divided into four groups corresponding to water mass (e.g. Ozawa et al., 1999). Robertsonites, Krithe spp., and A. dunelmensis together inhabit the Japan Sea Proper Water 
New ostracod (Crustacea) species of the genus Robertsonites

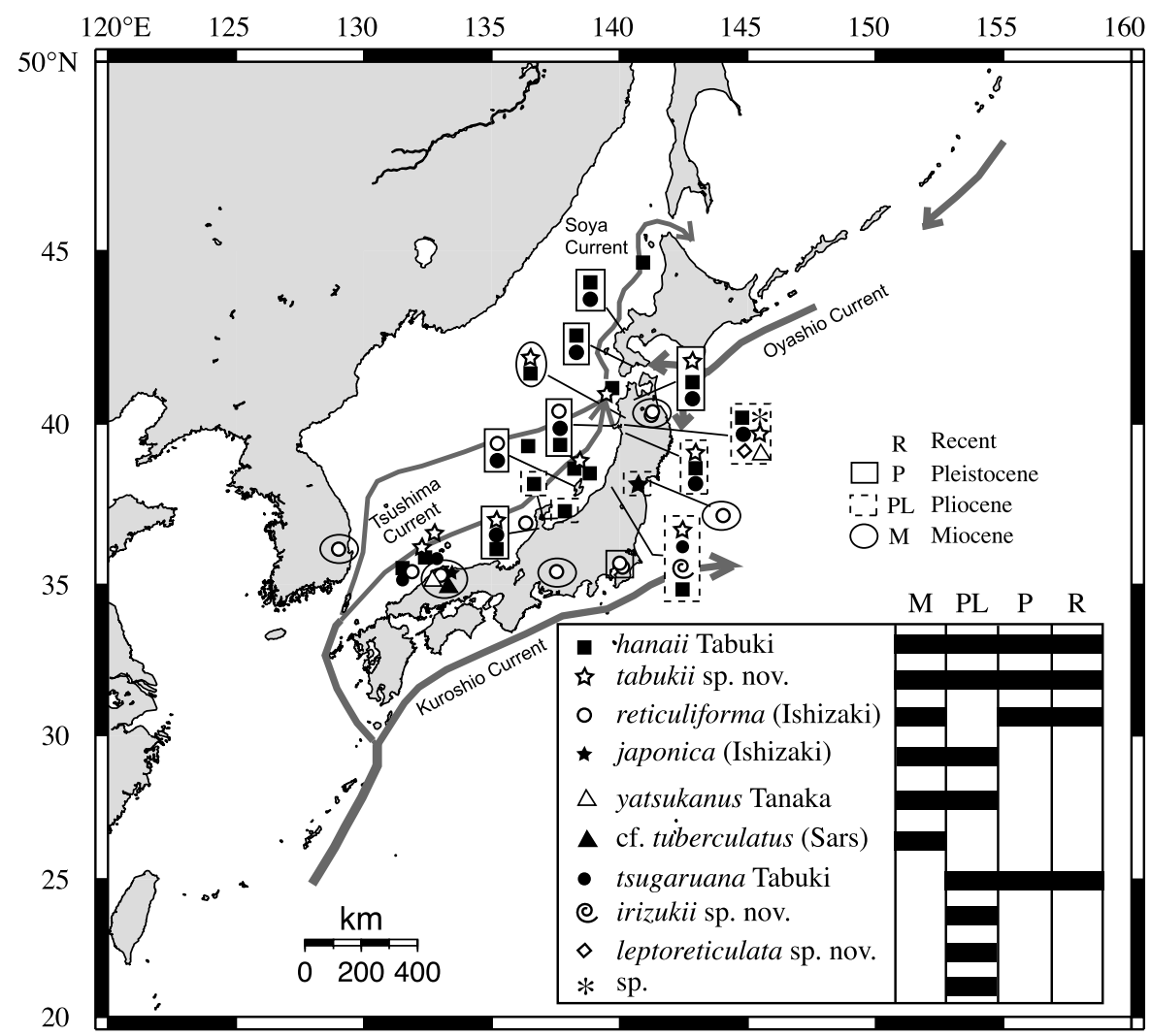

Fig. 6. Distribution and occurrence of fossil and Recent species of the genus Robertsonites around Japan.

mass, which is characterized by low temperatures (approximately $0-1{ }^{\circ} \mathrm{C}$ ), high salinity (about $34 \%$ ), and large volume (Isoda, 1994). This water mass, in which $R$. hanaii, $R$. reticuliforma, $R$. tabukii and $R$. tsugaruana live, occurs deeper than $150 \mathrm{~m}$ in the Sea of Japan. Robertsonites is, therefore, a numerically significant bathyal taxon of the ostracod faunas of Japan and the adjacent areas. Fossil data from the Plio-Pleistocene confirm that Robertsonites should be treated as a bathyal taxon in the Sea of Japan. Fossil Robertsonites occur with Krithe and Acanthocythereis (Yamada et al., 2002b), and the relative abundance of these taxa increases in horizons in which the relative abundance of sublittoral taxa decreases (Yamada et al., 2002a).

Fossil ostracod data from Japan also suggest that Robertsonites occurred around Japan from the Miocene to the Recent (Fig. 6). The oldest occurrence of this species ( $R$. cf. reticuliforma) in the world is in the Fujina Formation, Shimane Prefecture, southwest Japan (Tanaka et al., 2002), although the specimens from the Fujina Formation are not identical to $R$. tuberculatus. No occurrences of $R$. tuberculatus from other high-latitude seas in the Northern Hemisphere have been recorded before the Miocene. Thereafter, $R$. tuberculatus does not occur in strata around Japan, but is recorded in highlatitude seas during the Pliocene in the Sea of Japan. The highest diversity of Robertsonites is found in the Pliocene, and may correlate with the history of ostracod evolution in the Sea of Japan. However, it is interesting that no new species of Robertsonites appeared after the Pleistocene.
Robertsonites leptoreticulata was first reported as Robertsonites sp. 3 from a Sasaoka Formation section (Yamada et al., 2002a), where it occurs abundantly, but this species has not been reported elsewhere. The relative abundance of this species varies between zero and $38 \%$ in the studied section, and the horizons containing the species are restricted to the Sasaoka Formation (Yamada et al., 2002a). Ishizaki \& Matoba (1985) investigated the ostracod fauna of the Sasaoka Formation in other nearby sections, but $R$. leptoreticulata was not recorded.

From comparison with studies elsewhere, it is unusual for Robertsonites to be the most abundant species in any sample, or for the relative abundance of the genus to be more than $40 \%$ of the total abundance. In Recent sea-floor deposits in the Sea of Japan, the relative abundance of Robertsonites taxa exceeds $40 \%$ in one sample taken from a depth of $190 \mathrm{~m}$ off Shimane, southwest Japan (Ikeya \& Suzuki, 1992). One sample from the Pleistocene Omma Formation of central Japan is characterized by an abundance of $R$. hanaii, which constitutes $67 \%$ of the total abundance (Ozawa, 1996). In the Sasaoka Formation, $R$. leptoreticulata accounts for $38 \%$ of the total abundance. The relative abundance of $R$. tabukii also reaches 39\% in one horizon (sample Kwe103) in the upper Kuwae Formation. Thus, different species of the genus show distinct high peaks of relative abundance in each area. However, the reason for these marked peaks in one species is unknown.

Seven species in toto were observed from the Late Pliocene Sasaoka and Kuwae formations. Some of these occurred in only 
one area, but their relative abundances are significant enough to aid the reconstruction of the local palaeoceanography.

\section{ACKNOWLEDGEMENTS}

I would like to thank Toshiaki Irizuki (Shimane University) for many suggestions, kind help and for critical reading of the manuscript. I also acknowledge Yuichiro Tanaka (AIST), who gave me the chance to carry out this research. He kindly supported this work and also read the manuscript. I also appreciate the help of Kenshiro Ogasawara (University of Tsukuba). My special thanks are due to Kunihiro Ishizaki (Ishinomaki Senshu University) for critical reading of the first draft. I would like to thank Hirokazu Ozawa (National Science Museum) for valuable discussions and for providing unpublished data, and Moriaki Yasuhara (Osaka City University) for providing references. My appreciation would also be extended to referees for their critical reading of this paper and for making useful suggestions.

\section{Manuscript received 5 December 2002 Manuscript accepted 30 June 2003}

\section{REFERENCES}

Apostolescu, V. 1961. Contribution a L'etude paleontologique (ostracodes) et stratigraphique des bassins Cretaces et Tertiaires de L'Afrique Occidentale. Revue de L'institut Francais du Petrole et Annales des Combustibles Liquides, 16(7-8): 779-867.

Baird, W. 1850. The natural history of the British Entomostraca. Ray Society, London, 1-364.

Brouwers, E. 1993. Systematic paleontology of Quaternary ostracode assemblages from the Gulf of Alaska. Part 1: Families Trachyleberididae, Hemicytheridae, Loxoconchidae, Paracytherideidae. US Geological Survey Professional Paper, 1531: 1-47.

Cronin, T.M. \& Ikeya, N. 1987. The Omma-Manganji ostracod fauna (Plio-Pleistocene) of Japan and the zoogeography of circumpolar species. Journal of Micropaleontology, 6: 65-88.

Cronin, T.M., Kitamura, A., Ikeya, N., Watanabe, M. \& Kamiya, T. 1994. Late Pliocene climate change 3.4-2.3 Ma: paleoceanographic record from the Yabuta Formation, Sea of Japan. Palaeogeography Palaeoclimatology Palaeoecology, 108: 437-455.

Elofson, O. 1941. Zur Kenntnis der marinen Ostracoden Schwedens, mit besonderer Berucksichtigung des Skageraks. Zoologiska Bidrag fran Uppsala, 19: 215-534.

Hase, H. \& Hirayama, J. 1970. Geology of the Gojome district. Quadrangle series, 1:50000 (in Japanese). Geological survey of Japan, $1-46$.

Hazel, J.E. 1967. Classification and distribution of the Recent Hemicytheridae and Trachyleberididae (Ostracoda) off N.E., N. America. US Geological Survey, Professional Paper, 564: 1-49.

Hiramatsu, C. \& Miwa, M. 1998. Neogene microfossil biostratigraphies of the Kitakanbara area in Niigata Prefecture and the geomorphology of an unconformity at the base of the Kuwae Formation. Journal of the Japanese Association for Petroleum Technology, 63: 301-314.

Honda, Y. 1978. Molluscan fossils from the Sasaoka Formation, Gojome Area, Akita Prefecture, northeast Japan. Saito Ho-on Kai Museum of Natural History, Research Bulletin, 46: 1-16.

Hoshi, H., Yamada, K. \& Irizuki, T. 2001. Paleomagnetic study of the Plio-Pleistocene Sasaoka Formation in the Gojome area, Akita Prefecture, northeast Japan. (in Japanese with English abstract) The Journal of the Geological Society of Japan, 107: 129-141.

Huh, M. \& Paik, K.H. 1992. Miocene Ostracoda from the Pohang Basin, Korea. Paleontological Society of the Korea, special publication, 1: $101-119$.

Ikeya, N. \& Suzuki, C. 1992. Distributional patterns of modern ostracodes off Shimane Peninsula, southwestern Japan. Reports of the Faculty of Science, Shizuoka University, 26: 91-137.
Irizuki, T. 1989. Fossil ostracode assemblages from the Pliocene Sasaoka Formation, Akita City, Japan-with reference to sedimentological aspects. Transactions and Proceedings of the Palaeontological Society of Japan, New Series, 156: 296-318.

Irizuki, T. 1993. Morphology and taxonomy of some Japanese Hemicytherin Ostracoda-with particular reference to ontogenetic changes of marginal pores. Transactions and Proceedings of the Palaeontological Society of Japan, New Series, 170: 186-211.

Irizuki, T. 1994. Late Miocene ostracods from the Fujikotogawa Formation, northern Japan-with reference to cold water species involved with trans-Arctic interchange. Journal of Micropalaeontology, 13: 3-15.

Irizuki, T. 1996. Lithology and Ostracoda from the Pliocene Tentokuji Formation along the southern marginal area of Mt Taiheizan, Akita Prefecture, northeast Japan. Bulletin of the Aichi University of Education (Natural Science), 45: 23-32.

Irizuki, T. \& Matsubara, T. 1994. Vertical changes of depositional environments of the Lower to Middle Miocene Kadonosawa Formation based on analyses of fossil ostracode faunas. Journal of the Geological Society of Japan, 100: 136-149.

Irizuki, T. \& Matsubara, T. 1995. Early Middle Miocene ostracodes from the Suenomatsuyama Formation, Ninohe City, northeast Japan and their paleoenvironmental significance. Transactions and Proceedings of the Palaeontological Society of Japan, New Series, 177: 65-78.

Irizuki, T. \& Sasaki, O. 1993. Analysis of morphological changes through ontogeny: genera Baffinicythere and Elofsonella (Hemicytherinae). In: McKenzie, K.G. \& Jones, P.J. (Eds), Ostracoda in the Earth and Life Sciences. A. A. Balkema, Rotterdam, Brookfield, $335-350$.

Ishizaki, K. 1966. Miocene and Pliocene ostracodes from the sendai Area, Japan. Science Reports of the Tohoku University, 2nd series (Geology), 37: 131-163.

Ishizaki, K. \& Matoba, Y. 1985. Excursion 5: Akita (Early Pleistocene cold, shallow water Ostracoda). Guidebook of excursions for the 9th International Symposium on Ostracoda. Organized Committee 9th International Symposium on Ostracoda, Shizuoka, 1-12.

Ishizaki, K., Irizuki, T. \& Sasaki, O. 1993. Cobb Mountain spike of the Kuroshio Current detected by the Ostracoda in the lower Omma Formation (Early Pleistocene), Kanazawa City, central Japan: analysis of depositional environments. In: McKenzie, K.G. \& Jones, P.J. (Eds), Ostracoda in the Earth and Life Sciences. A.A. Balkema, Rotterdam, Brookfield, 315-334.

Isoda, Y. 1994. Warm eddy movements in the Eastern Japan Sea. Journal of Oceanography, 50: 1-15.

Kamiya, T., Ozawa, H. \& Kitamura, A. 1996. Paleo-water mass structure during the depositional of middle part of the Omma Formation based on the changes of ostracode assemblage. (in Japanese with English abstract) HGI Report, 5: 145-165.

Kamiya, Y., Ozawa, H. \& Obata, M. 2001. Hokuriku: Excursion (Quaternary and Recent marine Ostracoda in Hokuriku district, the Japan Sea coast). Guidebook of excursions for the 14th International Symposium on Ostracoda. The Organizing Committee of ISO 2001, Shizuoka, 73-106.

Kobayashi, I. \& Watanabe, K. 1985. Geologic event in the eastern margin of Niigata Tertiary sedimentary basin, especially on MioPliocene unconformity. Science reports of Niigata University. Series E, (Geology and mineralogy), 5: 91-103.

Maiya, S. \& Inoue, Y. 1973. On the effective treatment of rocks for microfossil analysis. (in Japanese with English abstract) Fossils (Palaeontological Society of Japan), 25-26: 87-96.

Matsui, S. 1985. Recurrent Molluscan Associations of the OmmaManganji fauna in the Gojome-Oga Area, Northeast Honshu, Part 1. General discussions of fauna and systematic notes on Gastropod and Scaphopodspecies. Transactions and Proceedings of the Palaeontological Society of Japan, New Series, 139: 149-179.

Neale, J.W. \& Howe, H.V. 1975. The marine Ostracoda of Russian harbor, Novoya Zemlya and other high latitude faunas, In Swain, F.M. (Ed.), Biology and Paleobiology of Ostracoda. Bulletin of American Paleontology, 65: 381-431.

Okada, Y. 1979. Stratigraphy and Ostracoda from the Late Cenozoic strata of the Oga Peninsula, Akita Prefecture. Transactions and 
Proceedings of the Palaeontological Society of Japan, New Series, 115 143-173.

Ozawa, H. 1996. Ostracode fossils from the Late Pliocene to Early Pleistocene Omma Formation in the Hokuriku district, central Japan. Science Report of the Kanazawa University, 41(2): 77-115.

Ozawa, H. \& Kamiya, T. 2001. Palaeoceanographic records related to glacio-eustatic fluctuations in the Pleistocene Japan Sea coast based on ostracods from the Omma Formation. Palaeogeography Palaeoclimatology Palaeoecology, 170: 27-48.

Ozawa, H., Ikehara, K. \& Katayama, H. 1999. Recent ostracode fauna in the northeastern part of the Japan Sea, off northwestern Hokkaido. In: Ikehara, K. \& Okamura, Y. (Eds), Preliminary report on researches in the 1998 Fiscal year. Geological Survey of Japan, 103-117.

Sars, G.O. 1866. Oversigt af Norges marine Ostracoder. Forhandlinger Videnskabs-Selskabet, Christania, 7: 1-130.

Shimamoto, M. 1984. Molluscan fauna and sedimentary environment of the Sasaoka Formation to the north of Akita City, northeast Japan. (in Japanese with English abstract) Tohoku University, Institute of the Geology and Paleontology, Contributions, 86: 1-25.

Shoji, M., Irizuki, T., Yamada, K. \& Tanaka, Y. 2002. Fossil ostracode assemblages from the lower part of the Pliocene Kuwae Formation, Niigata Prefecture, central Japan. Abstract of the 109th annual meeting of the Geological Society of Japan. The Geological Society of Japan, Tokyo, 144. (In Japanese)

Swain, F.M. 1963. Pleistocene Ostracoda from the Gubik Formation, Arctic coastal plain. Alaska. Journal of Paleontology, 37(4): 798-834.

Sylvester-Bradley, P.C. 1948. The ostracod genus Cythereis. Journal of Paleontology, 22(6): 792-797.

Tabuki, R. 1986. Plio-Pleistocene Ostracoda from the Tsugaru Basin, North Honshu, Japan. Bulletin of College Education, University of Ryukyus, 29(2): 27-160.

Tada, R. 1994. Paleoceanographic evolution of the Japan Sea. Palaeogeography Palaeoclimatology Palaeoecology, 108: 487-508.

Takano, O., Moriya, S., Nishimura, M., Akiba, F., Abe, M. \& Yanagimoto, Y. 2001. Sequence stratigraphy and characteristics of depositional systems of the Upper Miocene to Lower Pleistocene in the Kitakambara Area, Niigata Basin, central Japan. Journal of the Geological Society of Japan, 107: 585-604.

Tanaka, G., Seto, K., Mukuda, T. \& Nakano, Y. 2002. Middle Miocene ostracods from the Fujina Formation, Shimane Prefecture, southwest Japan and their paleoenvironmental significance. Paleontological Research, 106: 1-22.

Tsukawaki, S., Kamiya, T., Kato, M., Matsuzaka, T., Naraoka, H., Negishi, K., Ozawa, H. \& Ishiwatari, R. 1997. Preliminary results from the R.V. Tansei-maru Cruise KT95-14 Leg 2 in the southern marginal area in the Japan Sea - Part I: sediments, benthic foramin- ifers and ostracodes. Bulletin of the Japan Sea Research Institute Kanazawa University, 28: 13-43.

Tsukawaki, S., Kamiya, T., Ozawa, H. \& Kato, M. 1998. Preliminary results on the sediment samplings during the $R$. V. Tansei-maru cruise KT96-17 Leg 2 in the southwestern part of the Japan Sea-sediments, benthic foraminifers and ostracodes. Bulletin of the Japan Sea Research Institute Kanazawa University, 29: 67-89.

Tsukawaki, S., Ozawa, H., Domitsu, H., Tanaka, Y., Kamiya, T., Kato, M. \& Oda, M. 1999. Preliminary results from the $R$. V. Tansei-maru cruise KT97-15 in the eastern marginal part of the Japan Sea off Tsugaru Peninsula, northeast Japan-sediments, benthic and planktonic foraminifers, and ostracodes. Bulletin of the Japan Sea Research Institute Kanazawa University, 30: 99-140.

Tsukawaki, S., Ozawa, H., Domitsu, H., Kamiya, T., Kato, M. \& Oda, M. 2000. Preliminary results from the $R$. V. Tansei-maru cruise KT98-17 in the southwestern marginal part of the Japan Seasediments, benthic and planktonic foraminifers, and ostracodes. Bulletin of the Japan Sea Research Institute Kanazawa University, 31: 89-119.

Tsukawaki, S., Ozawa, H., Domitsu, H., Hirano, K., Maeda, T., Tomii, Y., Saito, S., Xuedong, X., Kamiya, T., Kato, M. \& Oda, M. 2001. Preliminary results from the $R$. V. Tansei-maru cruise KT99-14 in the central and northeastern marginal parts of the Japan Sea-sediments, benthic and planktonic foraminifers and ostracodes-(Part I: surface sediments). Bulletin of the Japan Sea Research Institute Kanazawa University, 32: 1-28.

Whatley, R. \& Boomer, I. 2000. Systematic review and evolution of the early Cytheruridae (Ostracoda). Journal of Micropalaeontology, 19: $139-151$.

Yajima, M. 1982. Late Pleistocene Ostracoda from the Boso Peninsula, central Japan. In: Hanai, T. (Ed.), Studies on Japanese Ostracoda. University Museum, University of Tokyo, Bulletin, 20: 141-227.

Yamada, K., Irizuki, T. \& Nakajima, S. 2001. Spatial and temporal distribution of fossil ostracode assemblages and sedimentary facies in the Lower Miocene Arakida Formation. (in Japanese with English abstract) Journal of the Geological Society of Japan, 107: 1-13.

Yamada, K., Irizuki, T. \& Tanaka, Y. 2002a. Cyclic sea-level changes based on fossil ostracode faunas from the Upper Pliocece Sasaoka Formation, Akita Prefecture, northeast Japan. Palaeogeography Palaeoclimatology Palaeoecology, 185(1-2): 115-132.

Yamada, K., Watanabe, M., Tanaka, Y., Miwa, M., Yanagisawa, Y. \& Irizuki, T. 2002b. Marine deposits in the Sea of Japan between 2.80 and 2.55 Ma-the Kuwae Formation, Niigata Prefecture, central Japan. Abstract with programs the 2002 Annual Meeting. The Palaeontological Society of Japan, 102. (In Japanese) 